in some phenomena than in others, and more evident at some moments than at others. The questions of the origin, the existence, and the value of species in such a system are ensily appreciated.

Thornhill, Feb. 23

\section{The Preponderance of West Winds}

IN NATURE of the 16 th inst. you appear to contest $\mathrm{Mr}$ Laughton's statement that west winds preponderate over east on the entire globe. I believe that Mr. Laughton is right as to the fact. We have no reason to think that the earth's atmosphere is acteil on from without by any force except the sun's heat ; if this is the case, the winds can have no effect whatever in either accelerating or retarding the earth's rotation ; and, conseqently, the east and west winds must exactly balance each other's effect, for if either were unbalanced it would have an effect, however small, on the earth's rotation. But " an east wind near the equator has more effect in retarding the rotation of the earth, than a west wind of equal extent and force at a higher latitude in accelerating it, just as a weight at the end of the long arm of a lever outweighs an equal weight at the end of the short arm. It is for this reason that the west winds, which are mostly in the higher latitudes, are of greater force, and probably cover a greater area than the east winds, which, under the name of trade winds, predlominate near the equator:"

This quotation is frum a letter of mine published in NATURE of 16 th Feb.

In the same number of NATURE there is a letter from $\mathrm{Mr}$. Laughton, maintaining that rain may be caused by fires or explosions. This is contirmed by a fact mentioned by Humboldt in his Cosmos, that he once saw an eruption of the volcano of Cotapaxi in the Andes, during which the cone became red hot, and rain fell at an unusual time of the year.

In the same number is a most interesting account of the Winter Meteorological Observatory on Mount Washington in New England. Mount Washington must be much more isolated than mountains 10,000 feet high generally are; and I hope the opportunity may not be lost of making comparative barometric observations, extending over a considerable time, at the summit and the base. In NATURE of I gth January, you published a letter of mine on the importance of such a comparative series.

Old Forge, Dunmury, Co. Antrim, March is JOSEPH JOHN MURPHY

\section{Morell's Geometry}

IT was with no small surprise that I found myself accused by Mr. I. R. Morell, more than once in last week's NATURE, of having overlooked the fact "that all the proofs in the work ('Essentials of Geometry') are taken from French and German sources." Nothing to my mind could be more obvious than that throughout my review in NATURE for Feb. 23, I was criticising the performance of a compiler. In one instance, indeed-Mr. Morell has surely not already forgotten it-I took the trouble to show how Amiot's demonstration of the fundamental properties of parallels had been mutilated by him. must protest, too, against his claim to freedom from censure on the ground that he has merely copied passages from the works of our highest authorities; for it is about as reasonable as a claim to sanctity would be on the part of one who habitually, it is said, quotes Scripture for his own purposes.

Utterly ionoring the italics which I introduced, to save comment, into his definition of a plane angle, Mr. Morell quotes the Greek of Euclid and the English of Thomson, in justification, apparently, of the aptness of the introduction of the notion of revolution, which no one contested. He compels me, therefore, to draw his serious attention to the fact that neither of these geometers, nor anyother to my knowledge, ever confused mankind as he has done by speaking of the "inclination of two straight lines to a common point."

Mr. Morell has, lastly, the audacity to defend his pretended demonstration, on p. 44, of the theorem that two triangles are equal in every respect when the sides of one are respectively equal to the sides of the other, by stating, first, that it "is based on the previons pages ( 42 and 43 ), overlooked by the Reviewer "' and, secondly, that it " agrees almost word for word with Legendre." The first of these statements is absolutely incorrect; on pages 42 and 43 , there is not a word upon which the demonstration in question could be based. With respect to the second state- ment, I admit that Mr. Morell's demonstration substantially differs from Legendre's, as given by Blanchet, in Prop. xi. Bk. I, only by the omission of four words; and to show, by a striking example, what mischief scissors can do in Mr. Morell's hands, I will supply the four missing words, between brackets, in the following reproduction of his demonstration :-

"Let $\mathrm{ABC}, \mathrm{DEF}$, be two triangles, having $\mathrm{AB}=\mathrm{DE}$, $A C=D F, B C=E F$, then angle $A=D$; for if they werc unequal, sides $\mathrm{BC}$ and $\mathrm{EF}$ would be unequal [by the previous proposition]. Therefore $A=D . "$

The fact that Legfendre's most essential previous proposition is nowhere to be found in Morell's "Essentials of Geometry," sufficiently accounts for the omission of the four words above inserted. Mr. Morell, however, has yet to realise the fact that these omissions of his have converted a genuine demonstration into a mere assertion, or rather into a flagrant "violation of the most obvious of all logical rules."

Mr. Morell threatens, if space be given him, to show, on his "own authority," that he has "good arguments for what has been advanced." Before he does so let me remind him that logical demonstration, like the multiplication table, is more a subject for direct apprehension than for argument.

\section{THE ReVIEWER}

\section{A Meteorological Question}

WHILE glancing the other day over the article "Meteorology," in the Supplement to the 4th, 5th, and 6th Editions of the Enc' clopxdia Britannica, I was surprised to find under the marginal heading, "Hauhber's Experiment," the following:- "It is conceived that a current of air in sweeping over the surface of the earth, must cease to exert any vertical pressure. But this assumption can hardly be reconciled with any strict principles in science, for the particles of air will not for a moment cease to gravitate, nor will any horizontal motion of them produce the slightest de. rangement in a perpendicular direction." Is not this a great mistake? QUARE

\section{A SUGGESTED NEW DIVISTON OF THE EARTH INTO ZOOLOGICAL REGIONS}

$\mathrm{T} T$ seems now to be generally agreed among zoologists who are specially conversant with the fauna of India, that " the Indian Region" of Dr. Sclater and others can no longer be regarded as a genuine or natural zoological division of the globe, and that India properly so called (from the Himálya to the sea), is rather a border territory where different zoological regions meet and are variously interposed, at the same time blending, as a matter of course, to some extent.*

This is a subject which has long occupied my thoughts, and $I$ am gradually arriving at the opinion that the present dry land upon our planet may be most naturally divided into seven zoological regions, which again are divisible into sub-regions, and these into provinces and sub-provinces.

I. The Boreal Region, which is divisable into: I. Arctic Sub-region, within the confines of the Arctic Circle, but also inclusive of the whole of Greenland, and of Foxland (west of Davis Strait and north of Hudson Strait). 2. Neo-septentrional Sub-region-North America. 3. Ne meridional Sub-region-Central America with the Antilles. 4. Andisian Sub-region-the chain of the Andes with Chili, Patagonia, and the Fuegian and Falkland Archipelagos. 5. Palæo-septentrional Sub-region-Europe and Asia south of the Arctic Circle, and north of the Pyrenees, Alp; Taurus, Elburz (south of the Caspian Sea), Hindu Kosh, and Western Himálya, extending from the British Islands to Northern Japan? 6. Palæo-meridional Sub-region-the countries adjacent to the Mediterranean, as Africa north of the Atlas (with Madeira, the Canaries, and the Azores) Spain, Italy, Dalmatia and Illyria, Greece, the islands of the Mediterranean and the Levant, Turkey, Asia Minor,

*Vide Mr. W. T. Blanford in the "Proceedings of the Asiatic Society." for September 1867, p. I45 "The fauna of India at the present day is a remarkable mixture of African and Malay forms. The idea, so com monly expressed in European books, of India belonging to the same geological [qu. zoological?] province as the Malay Peninsula and Southern China is quite erroneous." Vide also the same " Proceedings" for January 1868 p. 18 , January 1869, p. 40 , and July 1870 , p. 238 . 
Syria, Egypt, Palestine, Mesopotamia, Persia, N. Afghánstân, Pánjâb, Middle China, Southern Japan? 7. Mongolian Sub-region-Mongolia, Tibet, and Chinese Tartary.*

II. The Colnmbian Region.--South America, minus the chain of the Andes and the extreme south. Divided into -I. Brazilian Sub-region; the forest countries east of the Andes. 2. Pampian Sub-region; the Pampas territory. 3. Peruvian Sub-region; Bolivia, Peru, Chili, and the Gallápagos Archipelago.

III. The Ethiopian Region.-Africa, south of the Atlas and of Egypt. Divided into-r. Lybian Sub-region; extending from Senegal to Nubia and Arabia, the country. bordering on the head of the Persian Gulf (Mekran), S. Afghánstân, Beluchistân, and the desert country of N.W. Hindustân. An outlying strip of this sub-region extends along the cleft, or wady, continuous with the Gulf of Ormuz, in which is situate the depression of the Dead Sea and beyond it the Valley of the Jordan. 2. Nigritian Subregion; Negroland. 3. Caffrarian Sub-region; Southern Africa. 4. Indian Sub-region; Hindustân proper, or the plains of Upper India E. and S. of the N.W. desert; Dukhun, or table-land of the peninsula of India; and the intervening territory, inclusive of the Vindhaian ghâts; Coromandel coast; low northern half of Ceylon.

IV. The Lemurian Region.-Madagascar, the Mascarine Islands, Seychelles, \&c. Probably an extensive region of dry land formerly, but now for the most part submerged, where the coral formations occupy so extensive an area.

V. The Australasian Region.t The Indo-Chinese peninsula, together with the Indo-Malayan region of Wallace; the southern watershed of the Himályas,

- It may seem a bold idea to put forward, but I have an exceedingly strong impression that the Stannavoi mountains, and the country eastward of them, the Valley of the Amur and all Mantchuria, with the Korean (or Koriak? Peninsula, the country of the Tchuktchi who, though pastoral, are veritable Eskimo, (I adopt the spelling of Sir J. Richardson), the peninsula of Kamchatka (as Mr. F. Whymper spells 1t), the Kurile Islands, the Japanese Arch pelago in part, and the Island of Saghalian or Sankhalin, which separates th Gulf of Tahtary from the Sea of Ukhotsk, together with the Alaska ter tory, eastruard of Bering's Straits (constituting part of the mainland of America) appertain alike to my Neo-septentrional sub-region, however the area may be subdivisible into provinces and sub-provinces; the Palæoseptentrional, the Neo-septentrional, and Arctic sub-regions being there variously interposed, with a certain amount of blending as in all such cases. $\mathrm{Be}$ it remarked that the Ovis canadensis is identical on the Stannavo Mountains, those of Kamchatka, and the Rocky Monntain chain in North America; also that the insectivorous genus Urotalpa (even the species apparently) is identical in Western North America and Japan, and there are very remarkable ethnological affinities pervading the entire area, to which it is sufficient here thus cursorily to allude. Indeed, the Japanese themselves are more nearly akin to the Columbians (or redskins, the so called "America Indians") than to the Asiatic nations of pronounced Mongolian type to which latter the Fimo of Yeso and kindred Kamchatkadales strictlye, to which The Ovibos moschatus (or musk-sheep) is asserted to strictly appertain of Saghalian! May not the species prove, however, to be 0 in the Island of De Blainville, supposed hitherto to be however, to be Ovibos Pallantis of the Arctic-American Barren-grounds? If I mistak than . moschatus memory) the $O$ Pallantis is identical with If mistake not (writing from memory) the Pallantis is identical with the North American Böotherizun bombifrons of Trans-Atlantic palæontologists. O. moschatus would appear at one time to have been distributed over my Palæo-septentrional sub-region even to the area now constituring the British islands. The present Arcti sub-region must at that time have been co-extensive with the existen Palro-septentrional if not also the existent Neo-septentrional sub-regions. Together with Ovibos moschatus on the Arctic American Barren-grounds, the European and Asiatic Ursus arctos there exists, which is significant of a former connection with the major continent! The Barren-grounds phy sically resemble the "Tundras" of Siberia and likewise mountain Lapland. The more that I reflect upon what is known of the fauna and flora of the debatable land in the extreme N.E. of Asia, the more thoroughly do I fee convinced that the Stannavoi mountains constitute the true and real boundary between Asia and America. Southward of the Stannavoi mountains, in Mantchuria, the two continents blend. The Japanese archipelago belongs to America, and not to Asia; at least in great part, as indicated by the presence of the Urotalpa; but there is also a true Talpa indicative of both Palæo-septentrional and a Palæo-meridional relations, and Phosiantes versicolor and $P$. Söemmeringiz indicate the latter, while many of the insessorial birds of Japan indicate the former, and the bulbul of the genus Microcelis indicates an Australasian element, so that the Japanese Archipelago is, after all, a debatable land where different zoological regions and sub-regions meet and blend more or le:s: Cervus pseudaxis of the moun tain spine of Formosa, so rearly akin to the much smaller $C$. sika of Japan and the much largex $C$. mantchuricus of Mantchuria, again indicating the propriety of recognising a Japanese or Korean province of the Neo-septentriunal sub-region of the grand Boreal region. All qualified botanists will surely bear me out in this opinion.

"Austral-Asia as distinguished from Australia : approximately the same as "the Indian region" of Dr. Sclater, but shorn of the greater part of India properly so denominated. at least up to the zone of oaks and rhododendrons, and jungle-clad hill country of Southern India and of Ceylon, if not also certain fertile hill territory in Soutbern Arabia ; Lower and Eastern Bengal ; Philippine Islands Chinese islands of Hainan and Formosa (minus its mountain spine), and probably so much of the south of China as is inhabited by the Manis or pangolin, the Palcornis cyanocephalus, the genus Centropus, and other Australasian and Ethiopian forms. Divided into: I. Indo Chinese Sub-region-extending southward over one-half of the Malayan peninsula, as far as Pinang and Province Wellesley; Hainan and lowlands of Formosa, and more or less of the southern part of China. 2. Malayan Subregion-southern half of the Malayan peninsula, Sumatra, Banka, Borneo, Java, and Bali. 3. Philippian Sub-region (which has Melanesian affinities, as indicated by the presence of a peculiar species of cockatoo-mammiferous animals few in number), Philippine Islands. 4. Himályan Sub-region-the southern watershed of the Himályas, with the tárai region at its base, Asám, and Eastern and Lower Bengal (i.e. the Sundarbáns). 5. Cinghalese Subregion-the hilly parts of Ceylon (occupying the southern half of the island), those of southernmost India, and the Malabar ghâts; perhaps also the little-known fertile mountain territory of Southern Arabia, from which Mek ka is supplied with grapes and other fruit.

VI. The Melanesian Region.-Divided into: I. Australian Sub-region-Australia (minus York peninsula and part of Queensland), Tasmania. 2. Papuan Sub-region-. Papua, New Britain and New Ireland, Jilolo or Halmahira, Ceram, Buru, Moluccas, Aru Islands, and Timor Lât; Louisiade Archipelago ; York Peninsula and eastern half of Queensland (as far as the dividing range) on the mainland of Australia. 3. Celebesian Sub-region-the very remarkable island of Celebes, which has Australasian affinities, but subordinates to the present region: Islands of Lombok, Sumbáwa, Flores, Wetter, Timor, and Sandalwood Island. (Austro-Malayan region of Wallace.) 4 Antarctic Sub-region, inclusive of Kerguelin's Land.

VII. The Polynesian Region.-Divided into: I. Moarian* Sub-region-New Zealand, with the islets appertaining to it, inclusive of Macquairie Island (upon which far southern land a peculiar species of ground-parrake et inhabits, of a Polynesian genus-Cyanorhamphus). 2. Polynesian Sub-region-comprehending the Archipelagos of the Pacific, excepting those which appertain to the Columbian region.

All of these Zoological Divisions of the dry land upon the surface of our planet might be amply illustrated by an enumeration of the species and genera, or even higher groups, which are respectively peculiar to them. Thus, the presence of the true raven (Corvus corax) exactly coincides with the limits which are here assigned to the vast Boreal region, even to the Indian Pánjâb, and assuming that the so-called American species ( $C$. carnivorus and $C$ : mexicanus) do not really differ, which I believe to be the case, as likewise the so-called C. tibetanus; the sole exception being that of the Andisian sub-region, inasmuch as there is no Corvzts in all South America. Be it always remembered that the major and the minor continents approximate in the Northern Pacific, to say nothing of the connection between them afforded by the chain of the Aleutian islands, and that a remarkable wild mountain sheep (Ovis canadensis) inhabits both sides of the Pacific, and not only the peninsula of Kamchatka, but the Stannavoi mountains which lie west of the sea of Ochotsk.

The southern watershed of the Himálya (below at least the zone of oaks and rhododendrons) consists, decidedly, of an extension westward of the Australasian

* I propose Moaria rather than Maoria, following Dr. Sclater's example of Lemuria; naming the land from the indigenous " moa" genus (Dinorn's) rather than from the present Maori inhabitants. Of course, it is well known that in the Polynesian languages "moa" merely signifies a fowl: but it has become Ispecialised since the discovery of the extinct Dinornis genus by Europeans. 
region, and in the bird-class its connection with India is maintained chiefly by migratory species; and very many of the permanently resident species, which have been thought to be specially characteristic of the Himálya, are equally found more or less throughout the Indo-Chinese sub-region, and not a few of them even in the Malayan sub-region, although nowhere met with in India, properly so called (the extensive . Liothrix series of birds, for instance), while a few of them reappear as the same or as closely proximate (little altered) species in the hilly parts of Southern India and of Ceylon. On the other hand, as may be generally remarked of bordering subregions of different regions, there are some cases of mutual representation in the Himályan sub-region of the Australasian region, and the Indian sub-region of the Ethiopian region. The lángur monkey (Presbytes schistaceus) of the Himalya ; is thus a specialised form of the hunumân group of India, exemplified by the Bengal hunuman ( $P$. entellus) and others, this being a characteristic Indian division of the genus which has no representative eastward of the Ganges.

India, properly so called, is a land where sundry subregions appertaining to different regions meet, and are variously interposed. The Palæeo-septentrional sub-region of the Boreal region extends into the Pánjâb, while the Mongolian sub-region borders upon the S.E. Himálya; the southern flank of the Himálya constitutes the Himályan sub-region of the Australasian region, to which, perhaps, should be referred (as distinct provinces) the mountains of Southern India and of Ceylon; then the Lybian sub-region of the Ethiopian region extends as far as the desert country N.W of Delhi; and the rest of India, with the low northern half of Ceylon, constitutes the main part of the Indian sub-region of the Ethiopian region. The N.W. Himálya again passes northward into the Palæo-septentrional and southward (in the alpine Pánjâb) into the Palæo-meridional sub-regions. In a S.W. direction the Maldive and the Láccadive coralislands belong strictly to the Lemurian region of $D r$. Sclater, and I am not sure that the latter does not reach the mainland of India, to comprehend the Concan or low maritime country constituting the Malabar coast, and lying along the foot of the ghâts. India, therefore, instead of being the nucleus of a distinct zoological region, is a land of extraordinarily complex zoological affinities.

As regards North America, it may be observed that the migratory insessorial birds are of Columbian types, whereas the permanentiy resident species are of types cognate with those of corresponding latitudes in the major continent : as we likewise find, in Europe, that our feathered summer visitants are of tropical or juxtatropical forms, as exemplified by the roller, bee-eater, cuckoo, oriole, and the mass of small insectivorous genera; and the same has already been remarked with reference to the Himálya, viz. that as concerns the bird class, the connection of the southern flanks of the Himalya with the plains of India is chiefly maintained by the species which migrate to and fro. Among the gallinaceous birds of North America, the turkeys (Meleagris) are the only fowls which have spurred tarsi, indicating their affinity to so many of the major continent genera of poultry-birds, while the partridges of the same sub-region (Orty $x$ and Lophorty $x$ ) are not more different from major continent forms than are many of the latter from each other. The turkeys are assuredly not more peculiar in any respect than are the peafowl and the tragopans (Ceriornis) of Asia, and the same holds true of the North American colins or partridges, even admitting the affinity of the latter for the Odontophori of South America. The northern continent, however, has nothing corresponding to the curassows and guans (Cracide), or to the tinamou (Tinamidce) of the Columbian region, to its great family of toucans (Rhamphastida), motmots (Momotida), jacamars (Galbulide), puff-birds (Bucconida), cariámas (Cariamidce), trumpeter- birds (Psophiida), or its nandous (Rhaida); and of the enormous family of humming-birds (Trochilidce) it has only some four or five species as seasonal immigrants! Again, in the class of Mammalia it has no living representative of the Edentata, so characteristic of the Columbian region (though it did formerly possess the Megalony; $x$ ), nor of the marsupial true opossums (Didelphidce), save one species only in the southernmost Atlantic States of the Union; but it has a fair propurtion of Insectivora, which in South America the Didelphida completely replace. The rodent families Chinchillida and Caviida, I look upon as Andisian forms, even though the viscacha (Lagostomus tetradactylizs) represents the former in the Pampian sub-region of the Columbian region. The mammalia of the Neo-septentrional sub-region of the Boreal region are surely not more different from those of the Eur-Asian sub-regions of the same region than are those of the latter from one another, say the Mongolian sub-region from either of the rest. With regard to the Andisian sub-region, I am mainly induced from a consideration of its extinct mammalia (so different from those of the Pampas) to consider it as a southern extension of the American portion of the grand Boreal region, and especially from the occurrence not only of such an animal as the Mastodon andium, but also of the living llamas and alpácas (Auchenia), which have no other known kindred, existent or extinct, than the camels of the major continent. Nevertheless, as usual in bordering subrecions of different regions, there is an interposition of forms to a certain extent, as illustrated, on the one hand, by the existence of the viscacha on the Pampian subregion of the Columbian region, and by that of the edentate Chlamydophorus truncatus in the Andes.

The Neo-meridional sub-region of the Boreal region has much stronger affinities for the Columbian region upon which it borders than has the Palæo-meridional sub-region of the Boreal region for the Ethiopian region and for the Australasian region upon both of which it borders, which of course is attributable to its nearer proximity to the Equator bringing it within the influence of the tropical and periodical rainfall. The several regions which are subject to that rainfall in different meridians hold relations of analogy with each other, i.e. the Nigritian sub-region of the Ethiopian region, the Lemurian region, the whole Australasian region, the Celebesian and the Papuan sub-regions of the Melanesian region, and the Peruvian and Brazilian sub-regions of the Columbian region. Then, southward, in corresponding latitudes beyond the influence of the tropical rainfall, the same analogies hold between the Andisian sub-region of the Boreal region, the Pampian sub-region of the Columbian region, the Caffrarian sub-region of the Ethiopian region, and the Australian sub-region of the Melanesian region; while, again, south of the parallel of $40^{\circ} \mathrm{S}$. lat., the analogies (though still considerable) between the Patagonian sub-region and those parts of the Australian sub-region and the Moarian subregion which fall within the boundary indicated are, to some extent, less prominently marked. Ptilopachus and kindred strong-footed passerine birds in Patagonia, nevertheless, most readily call to mind Menura and Orthonyx in Australia, and Mohoua in Moaria or New Zealand.

Having submitted these views I reserve for another occasion the consideration of other classes of the animal kingdom; premising, however, that I am well aware of such facts as the utter absence of the Cyprinida (or carp family) in all America eastward of Bering's Straits, a group of fishes which is so immensely developed in S.E. Asia. So far as the classes of mammalia and birds are concerned, I think that I have about hit upon the true classification of zoological regions, and I wish, before returning to the subject, to avail myself of the critical $r \in$ marks of competent naturalists having reference to all classes.
E. BLyTh 